\title{
ERGONOMIC AND WORKFLOW STUDY \\ sciendo OF SAUSAGE PRODUCTION PROCESS IN THE CONTEXT OF MANUAL TRANSPORT TASKS
}

doi:10.2478/mape-2018-0088

Date of submission of the article to the Editor: 03/2018 Date of acceptance of the article by the Editor: 06/2018

MAPE 2018, volume 1, issue 1, pp. 695-701

\author{
Mgr inż. Patrycja Kabiesz \\ Dr inż. Joanna Bartnicka \\ Silesian University of Technology, Poland
}

\begin{abstract}
The aim of the article is to analyze the activities performed manually in a meat processing enterprise in the context of shaping ergonomic working conditions.

Based on observational methods, including metric measurements of workstations and an in-depth interview with employees of the enterprise, the activities realized in the production process of the selected sausage product were recognized, with particular emphasis on manual work. On the basis of ergonomic analyzes carried out with the use of 3D SSPP software, groups of activities were identified that carry an increased risk of static load and the occurrence of ailments in the musculoskeletal system. The results of analyzes form the basis for the development of a workflow improvement process resulting from the improvement of manual work conditions.
\end{abstract}

Keywords: manual transport, workflow, ergonomics, meat industry, technological process

\section{HUMAN ROLE IN THE PRODUCTION PROCESS}

The biggest geographical area in addition to the USA, where research in ergonomics work is Europe. This means that the human-centered approach is an important aspect in shaping professional activity and human protection on our continent (Bartnicka and Kabiesz, 2018). The awareness of the benefits of ergonomics in industrial processing plants is generally known (Słowikowski, 2004). Meanwhile, the degree of realization of ergonomics is very diverse in companies (Mleczko, 2016). Given that profits are the most important goal of employers, they should be presented with a cost-effective investment in order to encourage their interest in ergonomics (Valdez et al., 2017).

The costs incurred by the enterprise as a result of accidents at work refer to the employee's absentee costs, but also affect lower productivity and product quality (Hoła and Szóstak, 2017). According to data from the Central Statistical Office in Poland, in 2017 the number of injured in accidents at work totaled 88330 people, and the accident rate amounted to 6.84 (the number of victims per 1000 employed persons). The most important cause of accidents was incorrect behavior of employees $-60.5 \%$. In contrast, more than half $(53.2 \%)$ of the actions performed by the injured person at the time of the accident are moving and manipulating objects (including moving $36.2 \%$, handling 17\%, manual transport $14.9 \%$ ).

The basic tasks performed in an enterprise by the employee include manual transport work. Pursuant to the Ordinance of the Minister of Labor and Social Policy of 14 March 2000, manual transport work is any type of transport or maintenance of objects or materials by one or more employees, including moving them through: lifting, stacking, pushing, pulling, moving, rolling or carrying These are activities that are characterized by a significant level of risk and the possibility of injuries, in particular when work is carried out contrary to the regulations and recommendations regarding the minimization of existing burdens (Wójcik, 2004). For the employer this is a significant economic problem. The employer should ensure the use of appropriate organizational and technical solutions to eliminate the need for manual handling 
of materials. If it is not possible to exclude manual transport, the employer should provide employees with the necessary collective and individual protection measures in order to reduce the nuisance and risks associated with the performance of these activities (Goode et al., 2014). Taking the above considerations as the background of the research, the aim was to recognize the nuisance of works related to the activities carried out in the production process of the selected sausage product, with particular emphasis on manual work. In addition, on the basis of ergonomic analyzes performed using the 3D SSPP software, groups of activities have been identified that carry an increased risk of static loading and the occurrence of pain in the musculoskeletal system. Obtained results of analyzes form the basis for the development of a workflow improvement method resulting from the improvement of manual work conditions.

\section{MATERIAL AND METHODS}

The research was carried out in a company from Poland located in the Silesian Voivodeship, which currently employs 111 people. The company is involved in the processing of pork, the cutting of pork half-carcases, as well as the sale of meat and sausages. Currently, the plant produces about 150 kinds of finely divided, medium-crushed, coarsely crushed products, block products and smoked meats. In 2005, a new production hall with an area of $4000 \mathrm{~m}^{2}$ was built, where observational studies were carried out.

Observations connected with video recording and photographic registration have been conducted since the beginning of 2018. So far, the subject of observation was the production of medium-sized sausage (in the further part of the article the word "sausage" is used), in particular: organization of the production process, organization of work positions (including rhythm and work pace, position at work, work space). Additionally, metric measurements of selected work stations characterized by manual operations were made.

The acquired research material was collected and ordered thematically in a dedicated database.

This material then became the basis for the methodical development of a graphical representation of the relationship between two components affecting the quality and efficiency of working conditions, i.e. the ergonomics of manual work with particular emphasis on transport activities and workflow including in particular material flow, machines, workers. Such a link made it possible to identify key places in workflow processes, which require improvement in the area of working conditions, and thus the entire production process.

Ergonomic evaluation was made using 3D SSPP version 6.0.1.

\section{RESULTS}

Figure 1 presents a simplified overall technological process of sausage production including a list of rooms and individual activities carried out in them.

The sausage production process is carried out in 14 different rooms connected with each other by manually opening doors or vertical blinds.

A total of 42 activities performed by employees during the production of sausage were identified. These activities were divided into two groups. The first group are basic activities, which include 12 activities, including the division of half-carcases into basic elements, portioning meat for cooking elements, traditional meat curing, meat grinding, raw material mixing, stuffing casings, packaging, quality control, etc. The second group is the activities auxiliary, which includes 30 activities, among others, measurement of the temperature of the raw material, moving half-carcass, wrapping the pallet, labeling products, moving containers. In addition, all the aforementioned activities were assigned to three main categories: transport activities, technological activities and non-technological activities. In turn, each category has been divided into two subcategories: manual operations and operations using machines, devices or tools. Some activities due to the specificity of work have been assigned to several categories at the same time. Figure 2 shows the result of assigning activities to the appropriate categories against the background of the main groups of activities, i.e. basic and auxiliary. 


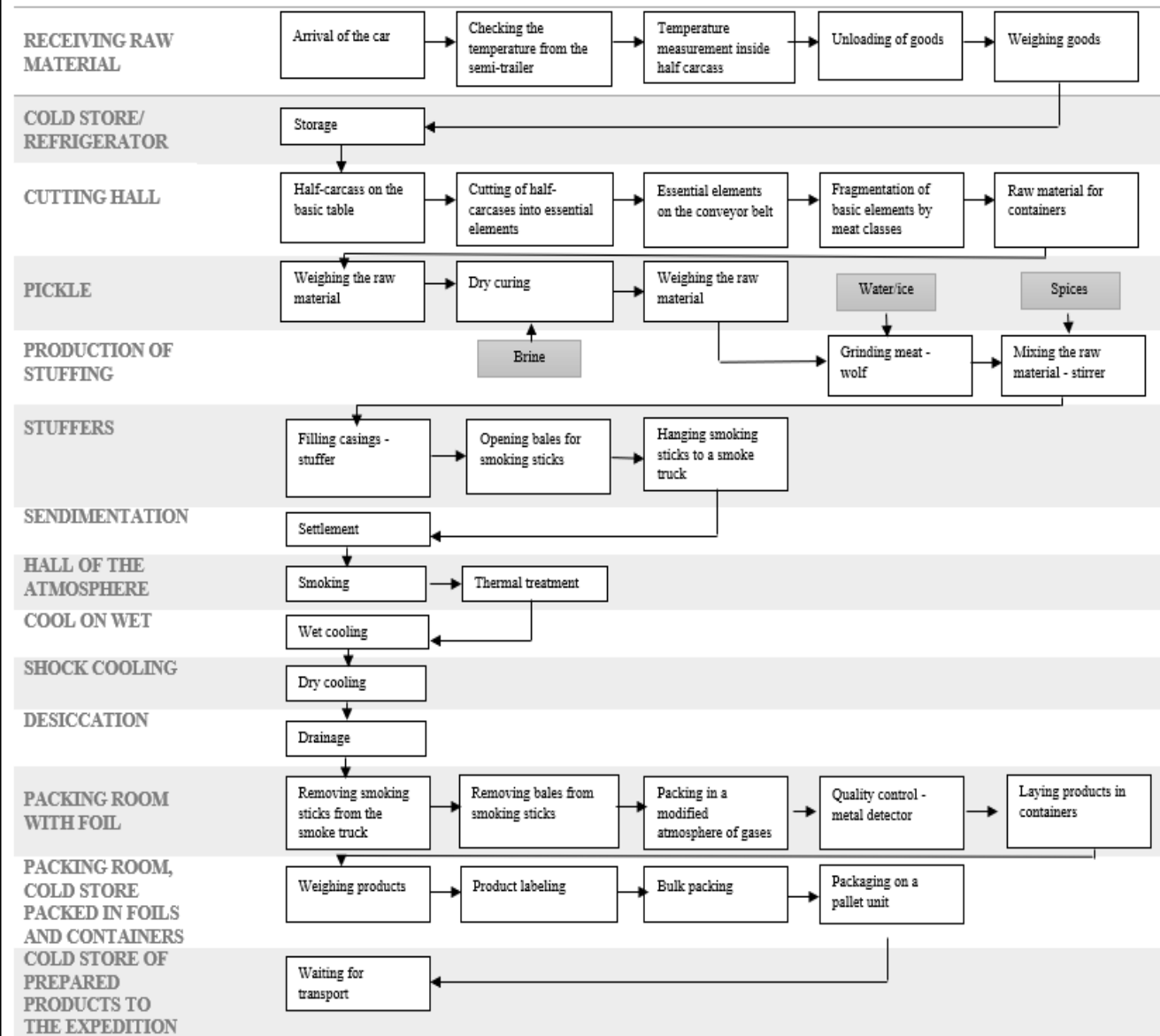

Fig. 1 Technological process of sausage

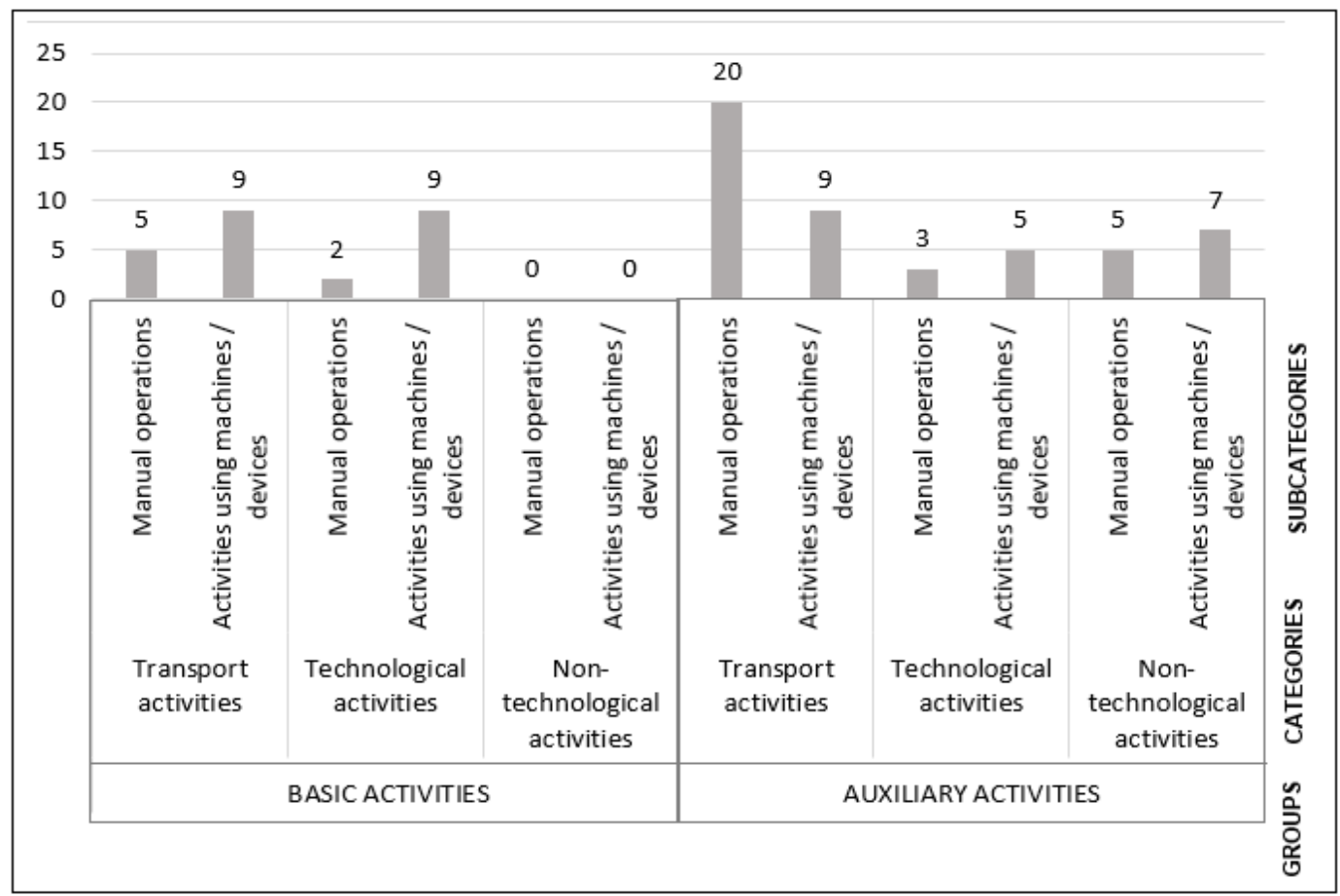

Fig. 2. Number of operations performed in the manufacture of sausage classified in the appropriate categories 
After the quantitative analysis of the basic activities, it follows that the most operations qualify for transport activities $56 \%$ (including manual $20 \%$ ). Technological activities account for $44 \%$ (including manual $8 \%$ ). Analysis of ancillary activities showed the share of $59.18 \%$ of transport activities (including manual $40.82 \%$ ), technological activities 16.33\% (including manual $6.1 \%$ ), non-technological activities $24.49 \%$ (including manual $10.20 \%$ ).

In the next stage, attention was focused on the results of research on manual transport work. Table 1 presents the result of photographic registration of employees during the performance of selected transport operations at individual work stations, supplemented by models of anthropometric features made in the 3D SSPP program. Anthropometric models, in turn, were used to evaluate the postural load. The choice of activities took place gradually on the basis of two criteria: (1) the most frequently accepted body positions; (2) the longest-held body positions clocked as a total percentage of the work shift time in which the position is received. Works in the cutting hall and production hall, where typical manual transport operations were not identified, are not included here.

Table 1

Photos of employees during transport operations at workstations

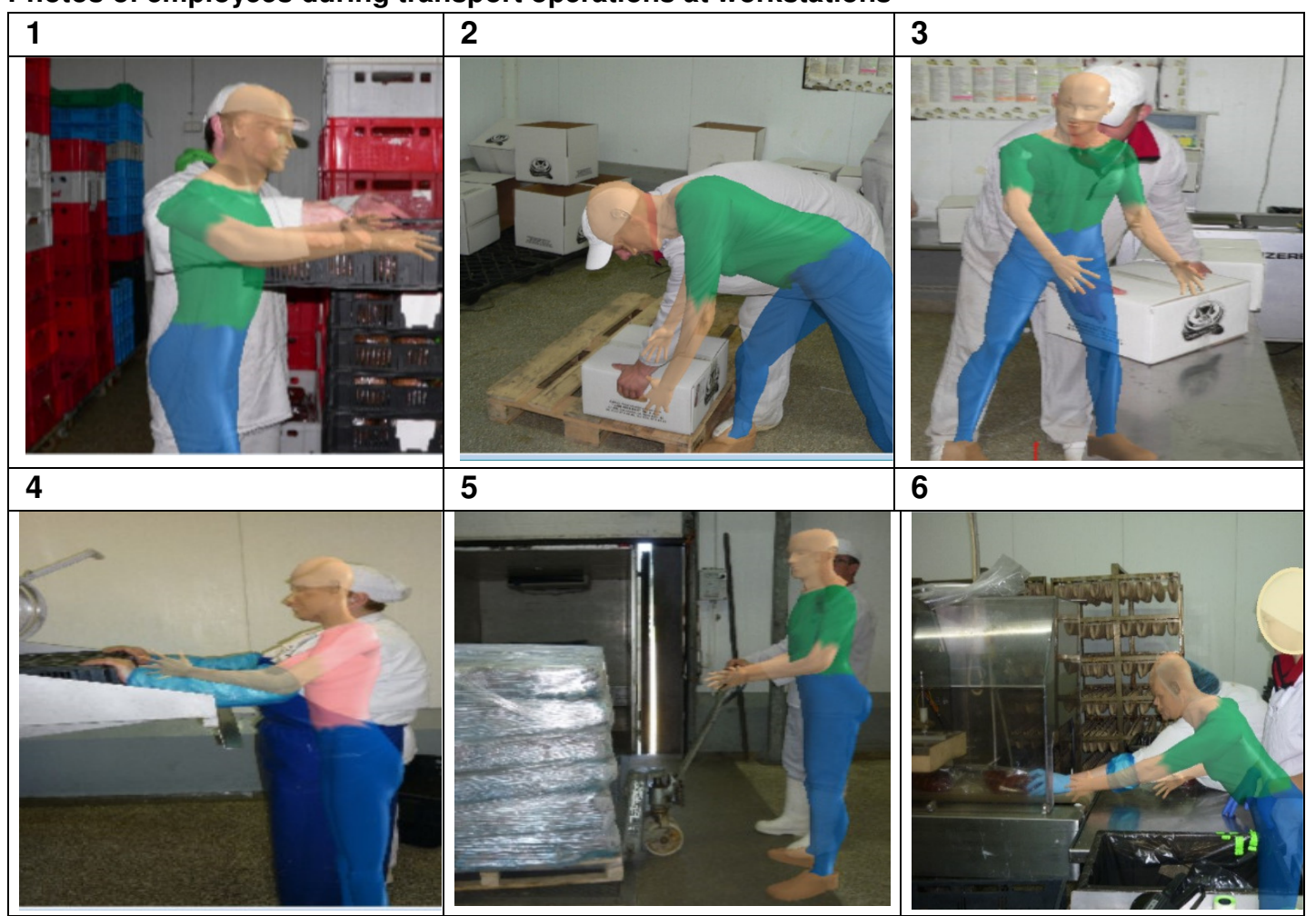

Table 2 presents the results of ergonomic analysis based on the developed models of anthropometric features. In particular, the analysis includes the value of spinal compresssion L4/L5 in [N] and the values of the Strength Percent Capable that represents a summary of the strength analysis for the major joints strengths (3D Static Strength Prediction Program ${ }^{\mathrm{TM}}$ Version 7.0.4 User's Manual). 
Table 2

Results of the analysis of models of anthropometric features

\begin{tabular}{|c|c|c|c|c|c|c|c|c|c|}
\hline & \multirow{2}{*}{ Name of the hall } & $\begin{array}{l}\text { 3D low back } \\
\text { compression }\end{array}$ & \multicolumn{7}{|c|}{ Strength Percent Capable [\%] } \\
\hline & & $\stackrel{\text { Pُ }}{\stackrel{J}{J}}$ & $\frac{\overline{\underline{n}}}{3}$ & $\begin{array}{l}3 \\
\frac{3}{4} \\
\bar{w}\end{array}$ & 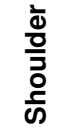 & $\begin{array}{l}\text { 온 } \\
\text { 은 }\end{array}$ & 음 & 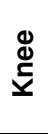 & $\frac{\frac{0}{x}}{\frac{1}{\alpha}}$ \\
\hline 1 & $\begin{array}{l}\text { Packing room, cold store packed in } \\
\text { foils and containers_1 }\end{array}$ & 2127 & 70 & 99 & 93 & 94 & 91 & 92 & 86 \\
\hline 2 & $\begin{array}{l}\text { Packing room, cold store packed in } \\
\text { foils and containers_2 }\end{array}$ & 4148 & 98 & 99 & 99 & 70 & 31 & 43 & 49 \\
\hline 3 & $\begin{array}{l}\text { Packing room, cold store packed in } \\
\text { foils and containers_3 }\end{array}$ & 2685 & 98 & 99 & 99 & 91 & 89 & 94 & 85 \\
\hline 4 & Container washer & 850 & 99 & 100 & 99 & 98 & 98 & 99 & 99 \\
\hline 5 & Receiving raw material & 731 & 99 & 100 & 100 & 99 & 98 & 99 & 99 \\
\hline 6 & Packing room with foil & 2164 & 99 & 100 & 99 & 95 & 92 & 96 & 94 \\
\hline
\end{tabular}

The result of the observation of the positions taken during manual transport activities showed typical states of somatic relations, which are: an inclined or deeply inclined position, twisted torso and neck.

\section{DISCUSSION}

In the production of sausages in most stages there are manual transport works, which are largely performed in unnatural body positions. The reason lies both on the side of employees who perform work in a routine manner, without sufficient ergonomic awareness and on the organizational side related to the organization of work space, lack of auxiliary resources, lack of training in the safe handling of weights, etc.

The largest loads of the musculoskeletal system among employees occur in the packing room, cold store packed in foils and containers. In particular, containers is a department in which manual transport works dominate, consisting of laying, pushing, pulling, moving, and transporting heavy materials. However, the smallest load is in the departments of receiving raw material and container washer.

So many transport activities identified in the company result from the necessity of continuous product flow along with accompanying work measures within the entire plant. Each transport operation is associated with the stage of lifting, transporting and parking. Such complexity of the process is associated with higher risk in two areas: (1) professional due to high postural load of employees, which may lead to the occurrence of diseases or injuries (Mack et al., 1995); (2) organizational due to possible time losses resulting from the variable performance of the employee and possible downtimes caused by the lack of consistency of human and equipment activities.

Therefore, it seems reasonable to look for a link between the workflow and the conditions that shape the ergonomics of manual work, with particular emphasis on transport activities. This connection was presented in a symbolic way as a map representing the technological process with additional information about workflow and work ergonomics.

The first stage in the preparation of the map was the assignment of activities to the relevant departments and warehouses involved in the production process. Figure 3 shows the symbols used to illustrate the number of activities performed in a given production cell. 


\begin{tabular}{|c|c|c|c|c|c|}
\hline \multicolumn{2}{|c|}{ Transport activities } & \multicolumn{2}{|c|}{ Technological activities } & \multicolumn{2}{|c|}{ Non-technological } \\
\hline $\begin{array}{c}\text { Manual } \\
\text { operations }\end{array}$ & $\begin{array}{c}\text { Activities using } \\
\text { machines/ } \\
\text { devices/tools }\end{array}$ & $\begin{array}{c}\text { Manual } \\
\text { operations }\end{array}$ & $\begin{array}{c}\text { Activities using } \\
\text { machines/ } \\
\text { devices/tools }\end{array}$ & $\begin{array}{c}\text { Manual } \\
\text { operations }\end{array}$ & $\begin{array}{c}\text { Activities using } \\
\text { machines/ } \\
\text { devices/tools }\end{array}$ \\
\hline & & & & & \\
\hline
\end{tabular}

Fig. 3. Action symbols

The next stage of the analysis was the calculation of activities according to the defined 3 categories for individual departments and warehouses. Figure 4 shows the number of individual activities performed in the plant during production. Rooms numbered from I to XIV take direct part in the production process and are numbered according to the flow of raw material/product, while rooms numbers from XV to XVIII are warehouses from which materials or washing rooms are taken.

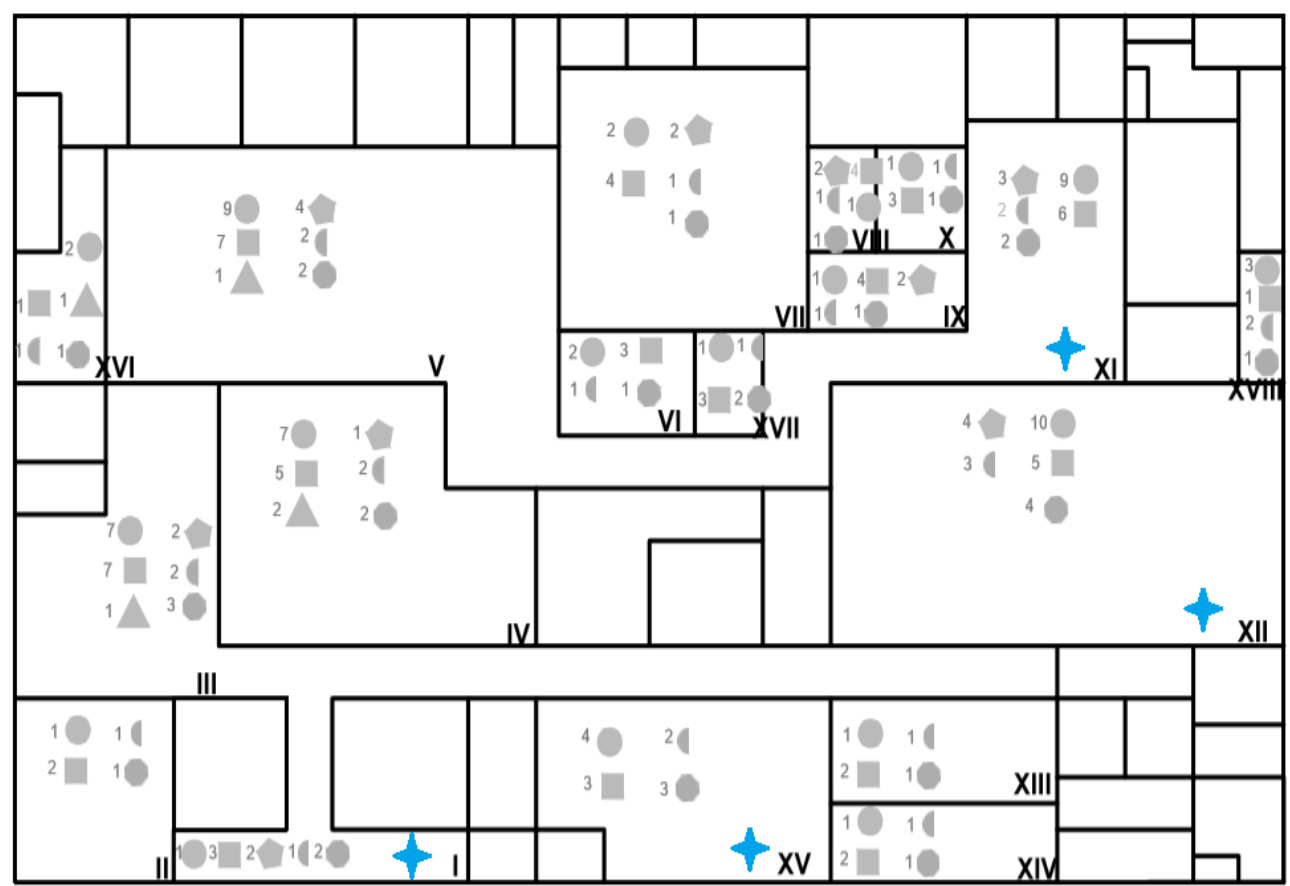

Note: I - receiving raw material, $70.22 \mathrm{~m}^{2}$; II - cold store, $99.51 \mathrm{~m}^{2}$; III - cutting hall, $139.82 \mathrm{~m}^{2}$; IV - pickle, 239.47 $\mathrm{m}^{2} ; \mathrm{V}$ - production hall, $250.92 \mathrm{~m}^{2} ; \mathrm{VI}$ - sedimentation, $51.48 \mathrm{~m}^{2}$; VII - hall of the atmosphere, $193.00 \mathrm{~m}^{2} ; \mathrm{VIII}$ - cooler, $16.20 \mathrm{~m}^{2}$; IX - shock cooling, $39.06 \mathrm{~m}^{2} ; \mathrm{X}$ - desiccation, $27.08 \mathrm{~m}^{2} ; \mathrm{XI}$ - packing hall with foil, $114.40 \mathrm{~m}^{2} ; \mathrm{XII}$ - packing hall, cold store packed in foils and containers, $305.19 \mathrm{~m}^{2}$; XIII - cold store of prepared products to the expedition, $72.48 \mathrm{~m}^{2}$; XIV - expedition at the stand, $49.46 \mathrm{~m}^{2} ; \mathrm{XV}$ - container washer, $152.24 \mathrm{~m}^{2} ; \mathrm{XVI}$ - warehouse additives, $46.52 \mathrm{~m}^{2} ; \mathrm{XVII}$ - wash, $18.37 \mathrm{~m}^{2} ; \mathrm{XVIII}$ - forming cartons, $19.25 \mathrm{~m}^{2}$

Fig. 4. The sum of individual activities performed in the production of sausage along with the flow of raw material

In addition, activities marked on the ergonomic analysis are marked on the map, indicating those that are burdened with an increased risk of work nuisance. These places were adopted as key in the workflow process for planning improvement activities. These actions should aim at eliminating the extreme positions of the body by introducing corrective ergonomics solutions while eliminating unnecessary and non-value-adding employee movements (bending, crouching, walking, etc.). By making corrective actions on the background of the workflow, it is possible to examine the impact of the changes made on the time efficiency of the entire production process. One of the methods of searching for solutions in this area is to enable 
employees to implement their own ideas that improve the ergonomics of workplaces. Employees who are closest to the job position are the first to notice factors that adversely affect the flow of operations and technological operations. Employee support by the company's management increases the motivation of employees to submit ideas that are later implemented into the company.

\section{CONCLUSION}

The increase in the interest in working conditions in meat establishments provides evidence of the presence of symptoms of musculoskeletal system overload in this occupational group. The key areas of ergonomic intervention in the course of the workflow within the production process of the selected product were identified as potential places for shaping the effectiveness of the process. Therefore, the next area will be the study of the correlation between the changed method of performing key manual transport activities and the time efficiency of the entire production process.

\section{ACKNOWLEDGEMENTS}

The paper is the result of statutory research carried out at the Institute of Production Engineering at the Faculty of Organization and Management of the Silesian University of Technology as part of a project number 13/030/BK_18/0039 called "Development of intelligent production methods as well as work and life environments in the context of production engineering challenges".

\section{REFERENCES}

Bartnicka, J. and Kabiesz, P. (2018). Znaczenie ergonomii w działalności przedsiębiorstw - przekrojowe studium literatury. In: Innowacje w zarządzaniu i inżynierii produkcji. Tom II. Opole: Oficyna Wydawnicza Polskiego Towarzystwa Zarządzania Produkcją, pp. 397-408.

C4e.engin.umich.edu3D, (2018). 3D Static Strength Prediction Program ${ }^{\mathrm{TM}}$ Version 7.0.4 User's Manual. Available at: https://c4e.engin.umich.edu/assets/ Manual7.0.4.pdf [Accessed 31 Mar. 2018].

Goode, N., Salmon, P.M., Lenne, M.G. and Hillard, P. (2014). Systems thinking applied to safety during manual handling tasks in the transport and storage industry. Accident Analysis and Prevention, 68, pp. 181-191.

Hoła, B. and Szóstak, M. (2017). An Occupational Profile of People Injured in Accident at Work in the Polish Construction Industry. Procedia Engineering, 208, pp. 43-51.

Mack, K., Haslegrave, Ch. M. and Gray, M. I. (1995). Usability of manual handling aids for transporting materials. Applied Ergonomics, 5, pp. 353-364.

Mleczko, K. (2016). Importance of knowledge in the interdisciplinary production processes of innovative medical tools. International Journal of Economics and Management Engineering, 10 (1), pp. 333338.

Regulation of the Minister of Labor and Social Policy of March 14, 2000 on health and safety at work on manual transport; Dz. U. 2000, No. 26, item 313, with d.

Słowikowski, J. (2004). Zastosowanie zasad ergonomii w przedsiębiorstwie - przegląd rozwiązań. Bezpieczeństwo Pracy, 4, pp. 24-26.

Stat.gov.pl, (2018). Central Statistical Office Official Website. Available at: https://stat.gov.pl/ [Accessed 06 Apr. 2018].

Valdez, R. S., McGuire, K. M. and Rivera, A.J. (2017). Current state and future directions. Applied Ergonomics, 62, pp. 43-71.

Wójcik, S. (2004). Ręczne prace transportowe. Warszawa: Państwowa Inspekcja Pracy, Departament Informacji i Promocji. 